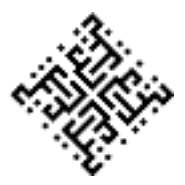

Tabligh: Jurnal Komunikasi dan Penyiaran Islam Volume 3, Nomor 1, Maret 2018, 68-90

Fakultas Dakwah dan Komunikasi, UIN Sunan Gunung Djati Bandung https://jurnal.fdk.uinsgd.ac.id/index.php/tabligh

\title{
Pesan Dakwah dalam Album Ketika Hati Bicara Karya Ebith Beat *A
}

\author{
Muhammad Tajul Arifin*, Atjep Muhlis, Nase \\ Jurusan Komunikasi dan Penyiaran Islam, Fakultas Dakwah dan Komunikasi, \\ UIN Sunan Gunung Djati, Bandung \\ *Email:mtajoelarifin@gmail.com
}

\begin{abstract}
ABSTRAK
Penelitian ini bertujuan untuk mengetahui pesan dakwah yang terkandung dalam lagu-lagu Ebith yang diusung dalam sebuah album berjudul "Ketika Hati Bicara", yang mencakup pesan akidah, akhlak, dan syariat. Metode penelitian ini adalah penelitian kualitatif dengan pendekatan analisis isi, yang merupakan suatu langkah yang ditempuh untuk memperoleh keterangan dari isi komunikasi yang disampaikan dalam bentuk lambang. Teknik pengumpulan data dalam penelitian ini adalah melalui observasi, wawancara, dan dokumentasi. Hasil penelitian menunjukkan bahwa, lagu-lagu Ebith yang diusung dalam album "Ketika Hati Bicara" sangat jelas menunjukkan keberadaan pesan dakwah, termasuk pesan akidah, akhlak, dan syari'ah di dalamnya, karena lirik lagu yang dinyanyikannya sama sekali tidak bertentangan dengan Quran dan Hadis. Hal tersebut dibuktikan dengan cara Ebith yang selalu berkonsultasi terlebih dahulu kepada yang lebih tahu tentang agama sebelum menuangkannya ke dalam sebuah lirik lagu.
\end{abstract}

Kata Kunci : Dakwah; Pesan; Analisis Isi; Ebith Beat *A

\section{ABSTRACT}

This study aims to find out the message of da'wah contained in music as well as Ebith songs carried in an album entitled "When the Heart Speaks", which includes the message of creed, morals, and shari'ah. This research method is a qualitative research with content analysis approach, which is a step taken to obtain information from the contents of communication delivered in the form of symbol. Technique of collecting data in this research is through observation, interview, and documentation. The results showed that, Ebith songs that were carried on the album "When the Heart Speaks" very clearly indicate the existence of the message of da'wah, including the message of 
Pesan Dakwah dalam Album Ketika Hati Berbicara Karya Ebith Beat A*

creed, morals, and shari'ah in it, because the lyrics of the songs sung in no way conflict with the Quran and Hadith. This is evidenced by the way Ebith is always consulted first to who knows more about religion before he poured it into a song lyrics.

Keyword: Da'wab; Messages; Content Analysis; Ebith Beat $A^{*}$

\section{PENDAHULUAN}

Islam merupakan agama yang universal dan selalu mendorong umatya untuk menyeru atau berdakwah sesuai kemampuan yang dimiliki oleh masing-masing individu. Dakwah bisa dilakukan dengan berbagai macam cara dan dapat menggunakan media apa saja seperti dakwah bisa dilakukan di atas mimbar, dakwah bisa melalui musik atau lagu bahkan di televisipun sudah banyak menayangkan film-film yang bernuansakan dakwah serta mengandung pesan dakwah. Pemanfaatan musik atau suara sebagai media dakwah bukanlah hal yang baru dalam dunia Islam, seorang sufi besar dari Persia, Maulana Jalaludin Rumi, beliau sering melantunkan syair-syair pujian kepada Allah SWT seperti halnya sebagian Wali Songo yang menyebarkan agama Islam di Indonesia dengan menggunakan alat musik gamelan yang dipandang sama pentingnya dengan dakwah itu sendiri. Dakwah melalui seni musik memang sangat banyak dilakukan oleh Islam Indonesia, dengan mengusung lirik-lirik keIslaman dari berbagai jenis aliran musik, yaitu Nasyid, Qasidah, Marawis, Dangdut, Pop, bahkan musik beraliran keras sekalipun seperti rock juga dapat dijadikan sebagai media dakwah (Aripudin, 2012:138). Seni merupakan bagian dari media yang bisa menjadi daya tarik bagi pendengarnya terutama seni suara, Al-Izzu bin Salam mengatakan "Adapun nyanyian yang dapat mengingatkan orang kepada akherat, tidak mengapa bahkan sunnah" (Umar, 1983:144).

Lagu merupakan refleksi dari pelaku seni sehingga mampu memberikan peranan penting dalam kehidupan bermasyarakat, selain itu lagu merupakan sarana penghibur yang paling efektif sehingga eksistensinya tidak dapat dipisahkan dalam kehidupan sehari-hari, apalagi dunia remaja sekarang ini yang tidak dapat dijauhkan dari lagu, hampir setiap kegiatan mereka ditemani lagu-lagu. Bahkan diwaktu sekolah pun mereka menyempatkn diri bersentuhan dengan lagu, mulai dari mendengarkan lewat media-media tertentu hingga sekedar mendengarkannya. Banyaknya minat masyarakat akan seni musik menjadikan musik sebagai penyampaian pesan dakwah yang cukup efektif, demikian pula yang dilakukan oleh Ebith Beat *A dengan album "Ketika

Tabligh: Jurnal Komunikasi dan Penyiaran Islam Vol. 3 No. 1 (2018) 68-90 
M. T. Arifin, A. Muhlis, dan Nase

Hati Bicara" musik yang bergenre hip-hop atau rapper Islami sebagai media penyampaian pesan dakwah merupakan suatu cara atau jalan untuk mengembangkan dakwah Islamiah melalui seni musik bagi kang Ebith.

Selain menyalurkan bakat dan hobi tetapi mempunyai tujuan yaitu bermain musik yang bisa bermanfaat bagi orang lain maupun diri sendiri dan mempunyai misi tersendiri. Kang Ebith Beat *A telah menghilangkan anggapan sebagian masyarakat terutama umat Islam, bahwa tidak semua musik bergenre Hip-hop selalu identik dengan hura-hura, namun juga bisa dijakan sebagai media penyampaian pesan dakwah dengan cara menyusup ke dalam kalangan mad'u yang menyukai musik, dengan begitu audience yang mendengar atau hafal lirik lagunya maka dengan sendirinya orang yang mendengarkan akan tahu pesan yang terkandung di dalamnya. Berdasarkan latar belakang di atas, maka pertanyaan spesifik dari jurnal ini adalah: 1) bagaimana pesan aqidah, dalam album Ketika Hati Berbicara karya Ebith Beat*A? 2) bagaimana pesan akhlak dalam album Ketika Hati Berbicara karya Ebith Beat*A? 3) bagaimana pesan syariat dalam album Ketika Hati Berbicara karya Ebith Beat*A?

Metode yang digunakan dalam penelitian ini adalah metode penelitian content analyze (analisis isi). Menurut Bakus content analyze (analisis isi) adalah analisis ilmiah tentang isi pesan suatu komunikasi (Muhajir, 2000: 68). Sedangkan menurut R. Holsti, analisis isi adalah suatu metode analisis pesan dalam satu cara yang sistematis yang menjadi petunjuk untuk mengamati dan menganalisis pesan-pesan tertentu yang disampaikan oleh komunikator. Metode analisis isi merupakan suatu teknik sistematik untuk menganalisis isi pesan dan mengolah pesan, atau suatu alat untuk mengobservasi dan menganalisis isi prilaku komunikasi yang terbuka dari komunikator yang dipilih. Pendekatan analisis isi merupakan suatu langkah yang ditempuh untuk memperoleh keterangan dari isi komunikasi yang disampaikan dalam bentuk lambang. Di samping itu, pendekatan analisi isi dapat digunakan, misalnya untuk mengetahui apakah lagu-lagu Indonesia sekarang ini lebih berorientasi pada cinta dari kritik sosial, atau apakah drama yang sering kali muncul di layar televisi akhir-akhir ini lebih mengungkapkan kehidupan cengeng daripada realitas, dan berbagai bentuk isi komunikasi lainnya (Rahmat, 2001:89). Adapun alasan menggunakan metode penelitian content analyze ini, karena yang menjadi objek dalam penelitian ini adalah syair lagu Ebith Beat*A dalam bentuk dokumen mp3, karena sesuai dengan penelitian Klaus bahwa analisis isi merupakan teknik riset untuk mendeskripsikan tujuan, 
sistematis, dan deskriptif kuantitatif yang menunjukan isi komunikasi atau analisis isi juga dapat menggunakan data-data yang bersifat kualitatif untuk mengungkap pesan yang terdapat dalam sebuat dokumentasi.

Data-data yang peneliti kumpulkan melalui observasi, yaitu mengamati langsung data-data yang sesuai dengan pertanyaan penelitian. Adapun instrumen penelitiannya adalah; 1) Data primer yaitu data-data yang berkaitan langsung dalam penelitian yaitu berupa dokumentasi lagu "Dina Amparan Sajadah" aransemen Ebith Beat A. 2) Data sekunder yaitu data pelengkap dan pendukung dalam penelitian yang berupa dokumen tertulis, yaitu literatur-literatur tentang lagu dan profil Ebith Beat A baik dari buku-buku yang relevan dengan penelitian, blog atau situs di internet.

Dalam mengumpulkan data, penulis menggunakan beberapa teknik, dengan beberapa cara mencermati, mengamati, membaca lirik lagu dan mendengarkan lagu Dina Amparan Sajadah yang telah diaransemen ulang oleh Ebith Beat A agar peneliti memahami dengan mudah tentang lirik lagu dan pesan dakwah yang terkandung di dalam lagu tersebut yaitu tehnik pengumpulan data studi kepustakaan, wawancara dan observasi.

\section{LANDASAN TEORITIS}

Pembahasan yang akan diuraikan dalam landasan teoritis ini mengenai yang berkenaan dengan beberapa teori tentang dakwah dan musik. Secara etimologi dakwah berasal dari bahasa Arab yaitu: da'a yad'u da'watan yang artinya memanggil, mengajak atau seruan. Dan yang kedua yaitu: da'a yad'u da'an yang artinya memanggil, mendo'a dan memohon (Yunus, 1990: 127).

Sedangkan dakwah menurut terminologi, mengandung banyak arti, tergantung dari sudut para ahli ilmu dakwah memberikan pengertian atau mendefinisikan dakwah itu sendiri, sehingga antara definisi satu dengan yang lainya terdapat kesamaan dan perbedaan. Jika di simpulkan dakwah dalam satu kalimat, dakwah mempunyai arti sebagai usaha yang dilakukan seseorang untuk mengajak umat manusia ke jalan menuju ridho Allah SWT, bertujuan untuk memperbaiki keadaan yang kurang baik menjadi lebih baik dan mengajak manusia menuju kebahagiaan dunia dan akhirat. Oleh karena itu, penggunaan bahasa tutur bagi seorang da'i dalam menyampaikan pesan- pesan dakwah lisan merupakan bagian yang integral dan harus dimiliki oleh setiap insan dakwah yang sesuai dengan nilai-nilai budaya lokal di mana masyarakat (Hikmat: 2011). 
Dalam Kamus Besar Bahasa Indonesia pesan mengandung arti perintah, nasehat, perintaan, amanat yang harus disampaikan kepada orang lain (Departemen Pendidikan dan Kebudayaan RI, 1999: 602). Pesan digunakan sebagai alat oleh komunikator untuk menyampaikna sesuatu kepada komunikan agar komunikasi yang dijalankan itu menjadi efektif dan langsung dapat diterima. Sedangkan dalam pengertian lain yang lebih khusus mengenai pesan dakwah menurut Bisri (1995: 28), pesan dakwah dapat dibedakan dalam dua kerangka besar. Pertama, Pesan dakwah yang memuat hubungan manusia dengan khalik (habblum minallah) yang berorientasi kepada kesalehan individu. Kedua, Pesan dakwah yang memuat hubungan manusia dengan manusia (Habblum Minannas) yang menciptakan kesalehan sosial.

Selain itu, pesan tidak hanya dipahami secara utuh, maksudnya setiap pesan mempunyai kategorisasi yang signifikan. Kata kategorisasi dalam Kamus Besar Bahasa Indonesia berarti penyusunan berdasarkan kategori (Departemen Pendidikan dan Kebudayaan, 1986: 516). Jadi kategorisasi pesan dakwah adalah susunan amanat-amanat yang ingin disampaikan berdasarkan kategorisasinya atau berdasarkan susunannya yang dapat mempermudah mad'u dalam menerima pesan dakwah. Adapun menegnai kategorisasi pesan dakwah, para pakar ilmuan dakwah banyak yang berbeda pendapat. Menurut Bachtiar (199: 33-34) kategorisasi dakwah meliputi akidah, akhlak, dan syari'ah. Sedangkan menurut Syukir (1983: 60) secara global kategorisasi pesan dakwah itu dapat diklasifikasikan menjadi tiga hal yaitu: masalag akidah, masalah syari'ah, dan masalh budi pekerti (akblakul karimah).

Selain pesan, yang harus dipahami dari struktur kegiatan dakwah adalah pelaku dakwah $\left(D a^{\prime}\right)$. Faktor subjek dakwah sangatlah menentukan keberhasilan aktivitas dakwah. Maka, subjek dakwah dalam hal ini Da'i maupun lembaga dakwah hendaklah mampu menjadi penggerak dakwah yang profesional. Baik gerakan dakwah yang dilakukan individual maupun kolektif. Di samping itu, kesiapan subjek dakwah baik penguasaan terhadap materi maupun metode, media dan psikologi sangat menentukan gerakan dakwah untuk mencapai keberhasilan (Munir, 2009: 13). Maka dari itu pelaku dakwah harus bersinegri dengan objek dakwah. Objek dakwah disini adalah masyarakat sebagai penerima dakwah (mad'u) baik individu maupun kelompok yang memiliki strata dan tingkatan yang berbeda-beda. Dalam hal ini seorang da'i hendaklah memahami karakter siapapun yang menjadi objek dakwahnya agar pesan dakwah yang 
disampaikan dapat diterima dengan baik oleh mad'u (Samsul, 2009: 19).

Setelah pelaku dakwah dan objek dakwah mampu bersinergi dengan baik hal selanjutnya yang harus diperhatikan dalam kegiatan dakwah adalah tujuan umum dakwah. Tujuan umum dakwah merupakan sesuatu yang hendak dicapai dalam seluruh aktivitas dakwah. Tujuan dakwah yang bersifat utama, di mana seluruh gerak langkah proses dakwah harus ditujukan dan diarahkan kepadanya agar terwujud kebahagiaan dan kesejahteraan hidup manusia di dunia dan akhirat. Tidak cukup hanya memperhatikan pesan, pelaku atau tujuan, kegiatan dakwah pula harus memperhatikan metode yang digunakan. Dari segi bahasa kata metode berasal dari dua kata yaitu "meta" yang berarti melalui dan hodos yang berarti jalan atau cara (M. Arifin, 1996: 61). Dengan demikian dapat diartikan bahwa metode adalah cara atau jalan yang harus dilalui untuk mencapai suatu tujuan. Dalam bahasa Yunani metode berasal dari kata methodos artinya jalan yang dalam bahasa Arab disebut Thariq (H.Hasanuddin, 1996: 35). Metode berarti cara yang telah diatur dan melalui proses pemikiran untuk mencapai suatu maksud. Menurut Kamus Besar Bahasa Indonesia (KBBI) media adalah alat, alat (sarana) komunikasi seperti koran, majalah, radio, televisi, film, foster dan masih banyk yang lainnya. Istilah media berarti alat perantara yang berasal dari bahasa Yunani, median jamaknya media. Adapun pengertian semantik yaitu segala sesuatu yang dapat dijadikan alat perantara untuk mencapai tujuan tertentu (Effendy, 2000: 65).

Pembahsan selanjutnya yang akan diuraikan dari landasan teori ini adalah tentang musik. Sebagaimana yang telah disinggung diatas, Musik adalah letusan ekspresi isi hati yang dikeluarkan secara teratur dalam bahasa bunyi atau lagu. Apabila dikeluarkan melalui mulut disebut vocal, dan apabila dikeluarkan lewat alat-alat musik disebut instrumental (Atam Hamju, 1986:9). Sebagian ulama berpandangan lebih moderat, bahwa lagu itu netral dalam arti bahwa hukumnya itu (halal atau haramnya) ditentukan bagaimana lagu itu digunakan. Lagu yang digunakan untuk mengiringi dansa-dansa atau mabuk-mabukan haram hukumnya, sedangkan lagu yang digunakan untuk memuji keagungan tuhan dibolehkan. Dengan kata lain, mereka berpendapat bahwa tidak ada larangan mengeluarkan nyanyian dalam Islam selam tidak membahayakan moral-moral Islam dan tidak menyesatkan kaum muslim. Secara lebih rinci, menurut Mulyana, M. A (1999: 57) menyebutkan bahwa ada syarat-syarat tertentu dalam bernyanyi, yaitu; 1) Pesan dalam lagu tidak bertentangan dengan ajaran Islam; 2) 


\section{T. Arifin, A. Muhlis, dan Nase}

Meskipun pesan lagu tidak haram, bila lagu diiringi dengan gerakan seksual yang sugesif, maka menyanyinya pun menjadi haram; 3) Islam menentang segala hal yang berlebihan, bahkan juga dalam ibadah, apalagi dalam hiburan. Kelebihan itu pastilah mengorbankan kewajiban lain; 4) Setiap orang adalah hakim yang terbaik. Bila suatu jenis nyanyian membawanya kedalam dosa, ia harus menghindarinya, jadi menutup pintu kedalam godaan; 5) Ada kesepakatan bila cara menyanyi (pakaian, penampilan, prilaku) dan kata-kata dalam lagunya sendiri bertentangan dengan Islam, maka nyanyian itu pun menjadi terlarang.

Selanjutnya, musik jika tanpa ada lirik yang mengeringi tidak akan menghasilkan satu kesatuan irama yang sempurna. Tentunya disetiap musik yang di mainkan tentu akan ada sebuah lirik yang mengiringi. Pengertian lirik sendiri adalah karya sastra yang bersifat curahan perasaan pribadi atau dapat juga dikatakan sebagai susunan kata sebuah nyanyian (KBBI, 1986: 528). Maka jika diambil kesimpulan, lirik lagu merupakan kumpulan kata-kata yang disusun oleh pencipta lagu. Penciptaan sebuah lirik lagu merupakan curahan pengarang lagu yang berasal dari pemikiran, perenungan atau pembelajaran, baik yang dilihat atau disarankan sehingga dituangkan dalam sebuah kata yang diiringi oleh alat musik atau tanpa alat musik. Lirik merupakan ikon dari sebuah lagu, tanpa lirik tak berarti sebuah lagu. Dari pengertian di atas dapat ditarik kesimpulan bahwa lirik lagu berarti karya sastra yang berisi curahan pribadi yang diungkapkan dengan suara berirama, atau juga susunan kata sebuah nyayian. Lirik lagu merupakan kata-kata yang diiringi, alat musik (instrumental). Sedangkan musik adalah bidang seni yang berhubungan dengan alalt-alat musik dan irama yang keluar dari alat-alat musik itu. Bidang musik membahas cara menggunakan instrumen music. Masing-masing alat musik mempunyai nada tertentu. Disamping itu, seni musik membahas cara membuat not, atau membuat bermacam aliran musik seperti musik vokal atau musik instrumental.

Lirik yang betemakan religius dan diiringi suara yang berasal dari alat musik merupakan metode yang sangat tepat sehingga akan semakin akrab dengan pendengar (mad'u) dan membuat mad'u menjadi hafal dan tahu maknanya yang terkandung dalam lirik lagunya dengan begitu mad'u dapat merasakan manfaat dan hikmahnya dari pesan yang disampaikan pencipta lagu memalui lirik lagu tersebut, dalam album Ketika Hati Berbicara karya Ebith Beat A menggambarkan kebobrokan manusia yang selalu lalai akan perintah Tuhannya, jadi dalam lirik lagunya mengandung 
pesan berupa ajakan, seruan, dan perenungan bagi mad'unya.

\section{HASIL DAN PEMBAHASAN}

Ebith Beat A salah seorang penyanyi bergenre hip-hop asal kabupaten Bandung tepatnya dari Rancaekek. Mempunyai nama asli Ebith Robby Drajat Priahutama, yang lahir pada 30 April 1980 dari pasangan Almarhum Bapak H. Ahmad Dudu dan Ibu Hj. Tati Hasanah anak ke 9 dari 9 bersaudara. Ebith menyelesaikan pendidikan dasarnya di SD Jelegong 2 tahun 1992 kemudian sekolah di SMP 1 Rancaekek selesai tahun 1995 dan SMU 1 Cicalengka 1998. Setelah menyelesaikan SMU-nya Ebith meneruskan kuliahnya di Sastra Prancis Universitas Padjajaran pada tahun yang sama. Akan tetapi, karena kesibukannya di dunia music Ebith sempat cuti kuliah sampai memutuskan untuk tidak melanjutkan kuliahnya di Universitas Padjajaran. Sempat berhenti di dunia pendidikan cukup lama, membuat dirinya merasa ingin kembali melanjutkan pendidikannya yang sempat terhenti alasan kesibukannya di dunia music. Akhirnya Ebith memutuskan melanjutkan pendidikannya kembali di Sekolah Tinggi Bahasa Asing (STBA) Yapari ABA Bandung dengan mengambil jurusan yang sama yakni Sastra Perancis.

Ebith Beat *A adalah seorang musisi asal Bandung yang menekuni jalur musik yang bergenre Rap/Hip-Hop. Di tengah macam-macam aliran musik, Ebith Beat *A menekuni jalur musik tersebut sebagai jalan hidup karirnya. Terlahir dari keluarga yang memang berjiwa seni Ebith Beat $* A$ sebelum mengawali karirnya sewaktu kecil Ebith sering diajak oleh sang ayah menonton pertunjukan-pertunjukan kesenian dan kebudayaan. Pada awal tahun 1998 Ebith Beat *A tidak menekuni jalur musik yang bergenre rap/hip-hop murni. Dia sempat menjadi vokalis band yang bernama Injected. Ia mengawali karir dijalur musik keras, yaitu hardcore, atau dikenal dengan musik metal.

Dalam musik tersebut cara menyanyi Ebith Beat *A tetap dengan cara rap yang dipadukan dengan teriakan dan musik distoris yang keras, selama bergabung dengan group band Injected Ebith Beat *A pernah mengeluarkan beberapa album dan tergabung dalam beberapa kompilasi. Musik rap/hip-hop yang ditekuninya merupakan suatu benang merah. Artinya, sejak terjun ke dunia musik sebgai vokalis, Ebith Beat $* A$ memang sudah menyanyi dengan gaya rap-nya. Nama Beat *A di belakang namanya pun menjadi identitas ketika memulai karir solonya.

Ebith Beat *A sempat membantu dan bergabung dengan beberapa 
grup musik lain, diantaranya band Kremlin yang mengusung aliran musik Hip-Hop Metal yang merupakan perpaduan antara jenis musik hip-hop dan metal. Beberapa waktu kemudian Ebith Beat*A memutuskan untuk keluar dari group band tersebut lebih memilih untuk solo karir. Beberapa musisi rap/hip-hop menjadi pengaruh baginya yang menjadikannya sumber inspirasi dalam menekuni karir di jalur musik tersebut. Selain musisi rap/hip-hop penyanyi pop, rock, $R \& B$, dan sebagainya juga turut menjadi inspirasinya, mulai dari Jay-Z, Eminem, Too Phat samapi Siti Nurhalidzah (Wawancara 01 Agustus 2017).

Seiring berjalannya waktu konsep musik hip hop dan sejenisnya tidak selalu mengandung kesan-kesan negatif, sebagaimana yang telah dipahami oleh sebagian masyarakat. Karena pada kenyataannya, musik hip-hop, musik pop, musik rock, dan musik lainnya juga bisa dijadikan sebagai alternatif media dakwah asalkan konsepnya tidak keluar dari norma-norma agama Islam ataupun menyalahi aturan syariat yang telah ditentukan. Pada tahun 2004, Ebith Beat *A ingin memberikan warna baru dalam karyanya yaitu dengan memadukan antara musik hip-hop dan lirik lagu yang tertuang di dalam pesan-pesan keagamaan dan alhamdulillaah Ebith Beat *A berhasil mengeluarkan album perdananya yang berjudul Round \#1 The Album dan di bawah naungan lebel Explosive Record. Meskipun pada awalnya berada dalam naungan indie label, namun album tersebut akhirnya bisa meraih kesuksesan. Single yang terkenal adalah "K.L.E.P.T.O" (Musnahlah) dan lagu "Saha ngaran Maneh Saha". Hal yang menjadi perhatian adalah selain lagunya, juga terletak pada tema dari lagu-lagu tersebut. Tema-tema yang mengangkat realitas sosial dengan lirik lirik yang tegas dan lugas bahkan cenderung keras.

Ebith Beat $*$ A termasuk rapper yang memiliki karakter atau ciri khas dalam membawakan lagu-lagunya. Mulai dari karakter suara atau vokal, sampai aksi panggungnya (gaya di atas panggung). Karena hip-hop mempunyai seluruh kultur gerakan artinya music hip-hop itu adalah bentuk seni musik yang mencakup beberapa kultur terdiri dari rap (MCing) yaitu bernyanyi dengan tempo yang cepat (rapalan), DJ-Ing (Cuttin and scratchin) adalah manipulasi rekaman terhadap groove yang khusus sehingga menghasilkan suara-suara yang aneh, dan breakdancing adalah sebuah tarian. Ebith Beat *A semakin banyak menarik perhatian masyarakat terutama kalangan muda yang menyukai musik hip-hop. Selain musiknya yang dikatakan easy Listening atau mudah dicerna, beragam 
tema lagu diciptakan dan dikemasnya dengan unik. Seperti lagu "Saha ngaran maneh saha" yang dalam liriknya memakai bahasa daerah (Sunda). Adapula lagunya yang berbahasa Inggris, Prancis, dan Indonesia tentunya terdapat dalam Albumnya. Lagu yang menjadi single Ebith Beat *A dalam album pertamnya yang terkenal adalah lagu "Saba ngaran maneh saba" cukup terkenal bukan hanya di Bandung saja, akan tetapi di beberapa daerah di Indonesia, walaupun lagu tersebut berbahasa daerah (sunda) kelebihan musik Ebith Beat *A yaitu simple dan dibuat melodius agar supaya enak di dengar.

Di lingkungan musisi lokal di Bandung sendiri, sosok Ebith Beat*A cukup dikenal, mengingat ia memang sudah lama berkecimpung di dunia musik. Bahkan sudah biasa diajak untuk berkolaborasi dengan musisi lain. Beberapa musisi yang pernah berkolaborasi dengan Ebith Beat *A yaitu PAS Band, Ten2Five, 711 dan Iwa-K rapper pendahulu yang terkenal di tahun 1990-an. Seiring dengan berjalannya waktu dan proses kedewasaan berpikir, Ebith Beat *A terkadang Ebith suka merasa malu dengan karyanya terdahulu yang dianggapnya terlalu keras. Berawal dari kesadaran diri sendiri dan dari berbagai pengalaman yang dimiliki, hingga pada akhirnya Ebith Beat *A memutuskan untuk menciptakan lagu-lagu yang bernuansa religi, meskipun musiknya tetap bergenre rap/hip-hop akan tetapi lirik lagunya bertemakan dakwah Islam dan alhamdulillah di awal tahun 2006 Ebith Beat *A mengeluarkan Album dengan judul "Ketika Hati berbicara". Dalam album ini Ebith juga menyertakan karyanya yang berkolaborasi dengan musisi terkenal seperti Darso, Raihan, Hadad Alwi dan Opik.

Sebagai seorang rapper, Ebith Beat *A tidak menjadikan karya yang dia ciptakan khususnya yang bertemakan Islam menjadi suatu beban, justru Ebith menjadikan hal tersebut sebagai motivasi untuk introspeksi diri, meningkatkan kualitas keimanan dan untuk selalu berbuat kebaikan. Walaupun demikian ada suatu dilema yang terkadang mengganggu, dalam artian bahwa Ebith Beat *A tidak mau disebut sebagai orang munafik atau sok tahu dengan mengingatkan orang melalui lagu tapi dia sendiri tidak melaksanakannya. Usaha yang dilakukannya untuk ha tersebut, Ebith Beat *A selalu bertanya kepada orang yang lebih tahu tentang agama, melalui Al-Qur'an dan Al-Hadits, alim ulama, buku-buku tentang pengetahuan Islam bahkan kepada teman kepada teman yang lebih mengetahui.

Pesan dakwah dalam lirik lagu Ebith Beat *A lebih diarahkan kepada hal-hal yang bersifat mengingatkan baik itu tentang kehidupan, 
kematian, ibadah sehari-hari, dan tentunya merujuk kepada aturan-aturan yang ada dalam Al-Qur'an sebagai sumber utama dan Al-Hadits sebagai sunnah Rasul. Dengan harapan bahwa melalui pesan dakwah dan music sebagai media, Ebith berharap karyanya dapat mengingatkan kewajiban dirinya terhadap Allah SWT dan sesama manusia dan mudah-mudahan karyanya juga dapat mengingatkan orang-orang yang mendengarkannya. Ebith juga berusaha mengajak para pendengar unuk belajar dan lebih memahami lagi tentang tujuan untuk apa hidup ini. Bagi orang-orang yang dianggap pengetahuan agamanya lebih, Ebith berharap dapat menambah kekurangan dan mengoreksi karyanya.

Suatu fenomena yang menarik, seorang rapper yang awalnya dianggap kontroversial seiring berjalannya waktu menjadi rapper yang tidak mementingkan dunia saja, akan tetapi mempunyai pandangan yang jauh ke depan (visi) tentang bagaimana karyanya bisa bermanfaat bagi dirinya dan orang yang mendengarkannya, dengan menjadikan karyanya sebagai sarana dan media untuk berdakwah.

Tabel 1. Klasifikasi Pesan Dakwah Berdasarkan Kategori

\begin{tabular}{|c|c|c|}
\hline Judul Lagu & Kategori Tema & Tema-tema Pokok \\
\hline Subhanallah & Akidah dan Akhlak & $\begin{array}{l}\text { Mengajak agar manusia selalu berdzikir, } \\
\text { dan berserah diri kepada Allah SWT }\end{array}$ \\
\hline $\begin{array}{l}\text { Ahli Dzikir, Ahli } \\
\text { Pikir, ahli Ikhtiar }\end{array}$ & Akidah dan Akhlak & $\begin{array}{l}\text { Keinginan untuk manusia agar tidak } \\
\text { melupakan Allah, agar mempunyai ilmu, } \\
\text { dan selalu berikhtiar. }\end{array}$ \\
\hline Cinta Hakiki & Akidah & $\begin{array}{c}\text { Keinginan untuk mengingatkan manusia } \\
\text { bahwasanya cinta hakiki itu hanyalah } \\
\text { kepada Allah SWT }\end{array}$ \\
\hline 24 Tahun & Akhlak & Muhasabah diri \\
\hline $\begin{array}{l}\text { Shalat Yang } \\
\text { Utama }\end{array}$ & Syariat & $\begin{array}{l}\text { Ajakan untuk selalu menjalankan shalat } \\
\text { wajib lima waktu }\end{array}$ \\
\hline Rasulullah & Akhlak & $\begin{array}{c}\text { Kerinduan yang mendalam kepada } \\
\text { Rasulullah Saw }\end{array}$ \\
\hline $\begin{array}{l}\text { Dina Amparan } \\
\text { Sajadah }\end{array}$ & Syariat dan Akhlak & berserah diri kepada Allah SWT \\
\hline Eling-Eling Umat & Syariat & $\begin{array}{l}\text { Keinginan untuk mengingatkan kepada } \\
\text { manusia yang sering kali lupa dengan } \\
\text { kewajibannya terhadap Allah SWT }\end{array}$ \\
\hline Panjeg Hate & Akidah dan akhlak & $\begin{array}{c}\text { Keyakinan dalam diri bahwa tidak ada } \\
\text { Tuhan selain Allah SWT }\end{array}$ \\
\hline
\end{tabular}




\section{Pesan Akidah Album Ketika Hati Berbicara}

Latar belakang penciptaan lagu Subhanallah, Ahli Dzikir dan Cinta Haqiqi yang tergolong pada pesan dakwah yang bertemakan pesan akidah merupakan hasil dari kontemplasi Ebith yang berfikir bahwa terkadang manusia ketika mereka sedang melakukan aktivitas kesibukaannya sering lupa kepada yang memberikan tenaga untuk melakukan kesibukan tersebut. Selalu lebih mementingkan kehiduan duniawi dan lupa urusan ukhrawi. Selain dari itu, Penciptaan dua dari tiga lagu tersebut masuk pada pesan yang bernuansa akhak. Seperti lagu subhanallah dan Ahli Dzikir. Pasalnya, penciptaan kedua lagu ini selain dilatarbelakangi untuk meningkatkan kepada Allah juga untuk memberikan kesempurnaan mempunyai akhlak yang mulia. Mengutip dari perkataan Ebith, bahwa ketika Ebith sedang bernyanyi, Ebith tidak hanya sekedar bernyanyi tetapi Ebith berusaha untuk tetap ingat kepada Allah SWT meskipun Ebith dalam keadaan sedang bernyanyi dan meskipun bernyanyi itu hanya sekedar hiburan tetapi Ebith ingin karyanya itu menjadi hiburan yang mengingatkan (wawancara, 01 Agustus 2017). Ebith Beat *A juga mengungkapkan bahwa terciptanya lagu ini juga merupakan bentuk syukur atas nikmat yang telah Allah berikan kepadanya selama ini.

Pada dasarnya inspirasi semua lagu yang terdapat dalam album Ebith Beat*A bermula pada ketika beliau mendengarkan salah satu group nasyid yang melantunkan dzikir tapi dalam tema musik. Berawal dari hal tersebut Ebith berpikir bahwa mereka (group nasyid) meskipun dalam kondisi bernyanyi tapi mereka tetap bisa melantunkan dzikir kepada Allah SWT melalui music dan lagu mereka. Pada awal lirik lagu ini (intro) Ebith mengajak para pendengar untuk berdzikir (mengingat Allah) dengan kalimat tasbih, tahmid, tahlil, dan takbir, menurut Ebith semua materimateri yang ada dalam lagu ini terdapat dalam Al-Qur'an dan Al-Hadits. Pada bait pertama, penulis menginterprestasikan perwujudan dari bentuk tauhid dalam penciptaan (tauhid khalqiyah), bahwasanya segala apapun yang berada didunia ini adalah hasil dari ciptaan Allah SWT, sudah sepatutnya bagi kita sebagai manusia untuk mensyukurinya. Pada bait ini juga Ebith mengingatkan kepada manusia untuk selalu mensyukuri pada setia anugerah. Pada bait kedua, Ebith mengajak para pendengarnya agar tetap selalu bersyukur dan ersabar ketika sedang ditimpa musibah dan meyakini bahwasanya setiap segala kejadian pasti ada hikmahnya Sabar itu ada tiga macam, yakni: sabar menghadapi musibah, sabar untuk mentaati segala sesuatu yang diperintahkan oleh Allah SWT dan sabar dalam 
menghindari kedurhakaan sabar yang diinterprestasikan Ebith dalam liriknya ini adalah sabar dalam menghadapi musibah. Dengan mengucapkan kalimat laa ilaaba illallah seorang akan selalu ingat kepada Allah dan begitu keimanannya akan selalu diperbaharui.

Menurut Ebith secara garis besar ada dua hal yang perlu digaris bawahi pada lagu yang mengandung pesan akidah yaitu pertama: mengingatkan kepada manusia untuk selalu berdzikir (mengingat Allah) dalam keadaan apapun dan yang kedua, pengembalian diri kepada Allah. Dzikir yang dimaksud dalam lagu ini implementasinya adalah berorientasi kepada ucapan dan tingkah laku. Tidak ada ibadah yang lebih utama bagi lidah setelah membaca Al-Qur'an selain drikrullah (mengingat Allah) dan menyampaikan kebutuhan melalui do'a yangtulus kepada-Nya. Seorang muslim dituntut untuk senantiasa berdzikir atau mengingat Allah SWT dalam segala kondisi, baik dalam keadaan senang maupun susah, lapang maupun sempit, karena dengan mengingat Allah SWT hati akan menjadi tenang. Rasa tenang itu sendiri adalah modal dasar bagi terciptanya kondisi kehidupan diri yang lebih stabil dan kondusif untuk senantiasa mengabdi kepada Allah SWT.

Ebith menekankan bahwa amalan yang paling utama adalah shalat, shalat adalah amalan yang pertama kali dihisab oleh Allah SWT, maka wajar bila begitu banyak ayat Al-Qur'an yang menganjurkan kepada manusia untuk senantiasa mengerjakan shalat. Allah tidak melarang kita untuk mencari rezeki, karena itu merupakan kewajiban kita untuk mencari penghidupan untuk di dunia demi kelangsungan hidup. Akan tetapi menurut Ebith penekanan pada bait pertama lagu ini adalah bagaimana cara yang kita gunakan dalam mencari rezeki tersebut. Karena, yang Allah SWT perhitungkan di akhirat kelak bukan harta bendanya, melainkan amalan-amalan kita di dunia. Ebith juga menambahkan bahkan hartalah yang nanti akan memberatkan kita di hari pembalasan karena keberadaan harta tersebut harus dipertanggungjawabkan.

Inti dari ketiga lagu ini adalah Ebith mengingatkan manusia untuk lebih mementingkan akidah kita untuk diperkuat, dibandingkan dengan mengurusi pekerjaan lain, karena dengan ibadahlah yang dapat menolong kita di akhirat nanti. Berikut penulis kutip salah satu yang menjelaskan nuansa pesan akidah yang terkandung dalam lirik lagu Subhanallah.

Lirik lagu Subhanallah yang mengajak untuk berzikir.

Intro:

Subhanallab Albamdulillah Laa ilaaha illallah Allahu Akbar Mari 
Pesan Dakwah dalam Album Ketika Hati Berbicara Karya Ebith Beat A*

sebutkan

Subhanallah Alhamdulillah Laa ilaaha illallah Allabu Akbar Mari sebutkan

Subhanallah Albamdulillah Laa ilaaha illallah Allahu Akbar Mari sebutkan

Subhanallah Alhamdulillah Laa ilaaha illallah Allabu Akbar Mari sebutkan

Ya Maha Suci Allah dengan segala bentuk dan ciptaan

Yang ada di dunia atau di alam sana

Berbentuk manusia atau pemandangan yang hanya bisa

Dilihat secara kasat mata

Semua tercipta olehnya dengan begitu sempurna walau

Satu dengan yang lainnya berbeda indah rupawan nan

Berwarna merupakan anugerah bagi kita semua

Ya! Rezeki yang telah diberi harus kita syukuri

Jangan kufur nikmat dan semua menjadi tidak bermanfaat

Apalagi dijadikan ajang maksiat ingat hari kiamat

---Chorus---

Segala puji bagi Allah, Alhamdulillah

Agar selalu tercurah terucap oleh mulut

Dan lidah supaya menjadi berkah

Supaya segala musibah sedang menimpa kita semua menjadi tabah Reff:

Subhanallah Alhamdulillah Laa ilaaha illallah Allabu Akbar Mari sebutkan

Subhanallah Albamdulillah Laa ilaaha illallah Allabu Akbar Mari sebutkan

Subhanallah Alhamdulillah Laa ilaaha illallah Allabu Akbar Mari sebutkan

Subhanallah Alhamdulillah Laa ilaaha illallah Allahu Akbar Mari sebutkan

Tidak ada tuhan selain Allah laa ilaaha illallah, laa ilaaha illallah, laa ilaaha illallah.

\section{Pesan Akhlak Album Ketika Hati Berbicara}

Setelah dianalisis terhadap data-data penelitian yaitu dari sepuluh lirik lagu Ebith yang terdapat dalam album ketika hati berbicara serta melalui wawancara langsung dengan Ebith Beat *A sebagai pencipta lagu 
M. T. Arifin, A. Muhlis, dan Nase

sekaligus vokalisnya, dapat diketahui selain tema atau lirik yang termasuk pada pesan akidah, Ebith Beath $A *$ mencoba menyampaikan pesan yang termasuk pada nuansa Akhlak. Seperti halnya pada lagu Subhanallah, Ahli dzikir, Rasulullah, 24 tahun shalat yang utama dan Dina Amparan Sajadah. Pokok pesan yang terdapat didalamnya, ada yang bersipat ajakan atau seruan dan nada juga yang bersifat peringatan (memberikan peringatan). Seperti dalam lagu "Subhanallah..Mari Berdzikir" lagu ini memiliki misi mengajak manusia untuk selalu mengingat Allah SWT dalam keadaan apapun, dengan demikian tema pada lagu ini adalah ajakan atau seruan. Dan lagu-lagu yang memberikan peringatan seperti lagu yang berjudul cinta yang hakiki (1 yang Maha Sempurna) Ebith mengingatkan kepada uamat manusia bahwa cinta yang benar-benar hakiki itu adalah cinta kepada Allah SWT yang Maha Sempurna.

Setelah sembilan lagu Ebith Beat *A dalam album Ketika Hati Berbicara yang diambil dari sumbernya, ternyata lagu-lagu Ebith Beat*A hampir keseluruhannya termasuk kedalah kategori Akidah dan Akhlak, karena lagu-lagu Ebith kebanyakan membahas mengenai sistem keimanan atau kepercayaan terhadap Allah SWT, dan menyangkut tata cara berhubungan dengan Allah (Habblu Minallah), dan tata cara berhubungan dengan manusia (Hablu minannaas), atau makhluk-makhluk Allah yang lainnya.

Ebith Beat $*$ A menjelaskan, bahwa dalam penulisan lagu-lagunya Ebith lebih memilih tema-tema yang menyangkut dengan keimanan, karena pada saat itu Ebith ingin lebih meningkatkan keimanan Ebith kepada Allah SWT. Karena keimanan manusia itu tidak selalu stabil dalam artian kadang keimanan seseorang itu bisa naik ketika dia mengerjakan hal-hal yang baik (amal soleh) dan terkadang juga menurun dengan kemaksiatan, jadi Ebith berharap dengan menciptakan Albium Religinya yang pertama ini bisa menjadi warning (peringatan) baik bagi dirinya untuk selalu mengerjakan amal shaleh maupun untuk para pendengar lagunya (Wawancara, 01 Agustus 2017).

Seperti yang telah dijelaskan dalam bab sebelumnya bahwa secara global materi dakwah Islam dapat diklasifikasikan menjadi tiga, yaitu 1) Aqidah, yaitu yang menyangkut sistem keimanan atau kepercayaan terhadap Allah SWT; 2) Syariat, yaitu serangkaian ajaran yang menyangkut efektivitas manusia dalam semua aspek kehidupan umat manusia. Masalah-masalah yang berhubungan dengan syariat bukan hanya terbatas pada ibadah kepada Allah saja, tetapi masalah-masalah yang berhubungan 
dengan pergaulan hidup atara sesama manusia; 3) Akhlak, yaitu menyangkut tatacara berhubungan baik secara vertikal dengan Allah SWT, maupun secara horizontal engan sesama manusia serta dengan seluruh makhluk-makhluk Allah SWT.

Maka materi dakwah yang terdapat pada lirik-lirik lagu Ebith Beat *A termasuk kedalam kategori: Akhlak ini memberikan gambaran kepada kita untuk senantiasa mempunyai budi pekerti yang baik baik itu kepada Allah dan kepada manusia. Seperti kutipan lirik lagu yang berjudul Akhlak dibawah ini, Ebith Beat $A^{*}$ memberikan cerminan akhlak baik yang diinterpretasikan melalui Rasulullah Saw sebagai uswah hasanah.

Reff: rasulullah penuntun kami

Kau tunjukan jalan illahi

Walau kami tak pernah mengenali

Kau cahaya sampai akhir nanti

Rindu kami padamu yaa rasulullah

Rindu kami padamu yaa habibullah

Senantiasa terlintas ingin bertemu

Kau terangi jalan hidup kami

Jalan yang lurus mengharap ridho ilahi

Reff: Rasulullah penuntun kami

Kau tunjukan jalan ilahi

Walau kami tak pernah mengenali

Kau cahaya sampai akhir nanti

Kasih sayangmu kau tunjukan pada dunia

Kesabaranmu tak habis walau kaum quraisy tak suka

Tetap tegar menunjukan kejalan yang benar

Allahuakbar allahuakbar yaa rahman yaa Rahim

Kau turunkan anugerah terindah bagi kami

Kau turunkan penerang jalan hidup kami

Salawat bagimu yaa rasulullah..salawat bagimu ya rasulullah..

Salaatullah salaamullah alaa thoha rasulillah

Salaatullah salaamullah alaa yaasiin habibillah

Salaatullah salaamullah alaa thoha rasulillah 
M. T. Arifin, A. Muhlis, dan Nase

Salaatullah salaamullah alaa yaasiin habibillah

Tawasalnaa bibismillah waa bil hadii rasuulillah

Wakulli mujaa hidilillah bi ahlil badri yaa allah

Reff: Rasulullah penuntun kami

Kau tunjukan jalan ilahi

Walau kami tak pernah mengenali

Kau cahaya sampai akhir nanti

Menurut Ebith yang menciptakan lagu yang berjudul Rasulullah tersebut merupakan ungkapan kecintaan dan kerinduan Ebith kepada Rasulullah. Lagu ini diciptakan Ebith sebelum Ebith menunaikan ibadah umroh dan ketika umroh Ebith berziarah ke makam Rasulullah. Setelah melakukan ziarah ke makamnya, rasa kecintaan dan kerinduan Ebith kepada Rasulullah semakin bertambah semakin besar, sehingga setelah pulang umroh Ebith sedikit mengubah lirik lagunya dan menambahkan beberapa bait pada lagu tersebut.

Ebith menjelaskan betapa berartinya Nabi Muhammad SAW., diutus ke dunia. Perjuangan Rasulullah mempertahankan ajaran agama Islam begitu dahsyat, meskipun banyak orang yang menentang ajaran beliau. Akan tetapi Rasulullah tetap tegar dan menjalankan perintah Allah SW'T untuk menyebarkan agama Islam. Maknanya Rasulullah saja yang menghadapi banyak cobaan dan banyak orang yang menentang tetapi beliau tetap tegar dan menjalankan perintah Allah SWT, hal tersebut patut dijadikan contoh. Ajaran agam Islam saat ini dihargai oleh agama lain.

Ebith menggambarkan tentang perjuangan Rasulullah dalam menyebarkan agama Islam begitu banyak cobaan, banyak yang menentang ajarannya dan kaum Quraisy yang tega menyakiti fisik Rasulullah hanya karena ingin menolak ajaran beliau. Tetapi Rasulullah tetap sabar dalam menghadapi cobaan. Di bait kedua ini juga Ebith menjelaskan bahwa begitu besar kecintaan Rasulullah kepada umatnya. Hal tersebut diabadikan dalam Al-Qur'an surat At-Taubah ayat 128.

\section{Pesan Syariat Album Ketika Hati Berbicara}

Pembahsan selanjutnya dalam menjawab rumusan masalah dalam jurnal ini adalah tentang Syariat. Masalah-masalah yang berhubungan dengan syariat bukan hanya terbatas pada ibadah kepada Allah saja, tetapi masalah-masalah yang berhubungan dengan pergaulan hidup atara sesama manusia. Beberapa lagu dalam album Ebith Beat $A^{*}$ yang tergolong 
dalam pesan syariat terdapat dalam lagu Shalat yang Utama dimana lagu ini menjelaskan tentang wajibnya seorang muslim mengerjakan ibadah shalat, karena shalat merupakan amalan sehari-hari yang akan pertama kali diminta pertanggungjawabannya oleh Allah SWT, maka lagu ini termasuk dalam kategori syariat. Selain itu, shalat adalah sebagai tiang dasar agama yang kedudukan hukumnya wajib. Ketika shalat ditinggalkan maka akan ada dosa yang menimpa umat muslim dimanapun mereka berada. Selain lagu berjudul Shalat yang utama, lagu lain yang termasuk dalam pesan syariat adalah lagu yang berjudul Dina Amparan Sajadah. Mengapa lagu ini masuk dalam kategori pesan syariat, karena lagu ini menceritakan tentang kepasrahan seorang hamba ketika dirinya tidak sanggup lagi untuk menyelesaikan seluruh persoalan kehiupan yang dialaminya. Karena syariat yang diberikan oleh Allah adalah berupa ibadah yang terlihat secara indera. Lagu terakhir yang termasuk dalam kategori syariat adalah lagu yang berjudul Eling-Eling Umat. Landasan mengapa lagu ini masuk kepada lagu yang mengandung pesan syariat adalah berdasarkan penuturan Ebith Beat A*.

Menurut Ebith lagu ini mengingatkan kita selaku umat muslim tentang wajibnya menyembah kepda Allah dan menggantungkan hidup hanya kepada-Nya dan meminta hanya kepada-Nya, karena pada zaman sekarang banyak sekali orang yang mengaku Islam akan tetapi lupa akan kewajibannya terhadap tuhan yang telah menciptakannya. Maka lagu ini termasuk dalam kategori syariat. Ebith Beat*A menjelaskan, bahwa dalam penulisan lagu-lagunya Ebith lebih memilih tema-tema yang menyangkut dengan keimanan, karena pada saat itu Ebith ingin lebih meningkatkan keimanan Ebith kepada Allah SWT. Karena keimanan manusia itu tidak selalu stabil dalam artian kadang keimanan seseorang itu bisa naik ketika dia mengerjakan hal-hal yang baik (amal soleh) dan terkadang juga menurun dengan kemaksiatan, jadi Ebith berharap dengan menciptakan Albium Religinya yang pertama ini bisa menjadi warning (peringatan) baik bagi dirinya untuk selalu mengerjakan amal shaleh maupun untuk para pendengar lagunya (Wawancara, 01 Agustus 2017).

Dalam album "Ketika Hati Berbicara", tema-tema pokoknya menyiratkan pesan-pesan agama Islam yang tidak sedikit bermuatan positif untuk mengajak manusia mengerjakan hal-hal yang baik dan meninggalkan hal-hal yang buruk (amar ma'ruf nabi munkar), Adapun tematema pokok dalam lirik-lirik lagu Ebith akan dikategorikan kepada tiga kategori sesuai dengan materi pesan dakwah yang pokok, sebagaimana 
yang telah di uraikan pada bab sebelumnya yakni akidah, syariah, dan akhlak. Menurut Ebith bukan hanya sekedar penumpahan seni dari jiwanya, tetapi seni baginya harus ada misi atau tujuan yang hendak disampaikan lewat penjelmaan bentuk seni (lirik lagu). Tujuan atau misi dari lirik-lirik lagunya mengandung nilai-nilai ajaran Islam, meskipun banyak sekali yang menggunakan seni sebagai hiburan semata, akan tetapi Ebith ingin karyanya merupakan hiburan yang tidak melalaikan kewajibannya terhadap Allah SWT. Lirik yang puitis itu pada umumnya merupakan komunikasi persuasif yakni ajakan, anjuran dan himbauan kepada pendengarnya menuju ke arah yang benar yakni sesuai dengan ajaran Islam. Adapun misi Ebith tersebut terlihat dari tema-tema pokok pada seluruh lagunya yang terdapat dalam album "Ketika Hati Berbicara". Berikut adalah salah satu dari tiga lagu yang mengandung pesan syarat yang berjudul shalat yang utama.

Intro:

ya Ebith beat a semoga lagu ini bisa menginspirasi kita

untuk lebih mendekatkan diri terhadap Yang Maha Kuasa

dan menjalankan ibadah yang paling utama

ibadah yang paling utama apa? sholat gitu loch!

oke, mari semuanya bernyanyi bersama

Reff: Allah tak melihat harta kita

Allah tak melihat jabatan kita

Allah hanya lihat ibadah kita

sholat yang utama

masih terbersitkah dalam pikiran kita

bahwa dunia adalah segalanya, harta benda yang akan menguasai

sehingga kita mencari harta mencari benda sampai lupa diri

sikut kiri sikut kanan hilangkan perasaan walau sesama kawan

sikut kiri untuk jabatan hari ini

sikut kanan bunuh teman dalam pangkuan

ya memang Allah tidak mengharamkan kita mencari harta, mencari

benda

namun sudah ditetapkan aturan 'cos yang Allah inginkan

yang Allah perhitungkan bukan harta atau benda

Reff: Allah tak melihat harta kita

Allah tak melihat jabatan kita

Allah hanya lihat ibadah kita 
sholat yang utama

berintrospeksi membenahi diri adalah hal yang luar biasa

ketika kita sudah hampir lupa dengan nilai agama

dan bertobatlah sebelum ajal menjemput kita

pikirkan kenapa harta dan benda lebih menguasai diri kita

renungkan ibadah apa saja yang sudah terlewat

membuat kita berdosa ya

apa yang menjadi alasan utama kita

menghalalkan segala cara mencari harta

apa yang membuat kita lupa terhadap-Nya

padahal hidup di dunia ini hanya sementara

apa yang akan kita pertanggungjawabkan di hadapan-Nya

ketika harta dan benda sudah tak lagi berguna

apa yang akan kita jawab, apa yang akan kita jawab

kenapa saya lebih mementingkan dunia (astaghfirullah al'azim)

lebih mementingkan harta dan juga benda

karena ketika saya lahir ke dunia (astaghfirullah al'azim)

dengan berbagai cara sedikit

yang membantu karena Allah ta'ala

tumbuh menjadi dewasa pun butuh biaya (astaghfirullah al'azim)

butuh harta dan juga benda

begitupun ketika saya tua (astaghfirullah al'azim)

saya perlu harta dan juga benda

untuk warisan anak cucu dan juga keluarga

Reff: Allah tak melihat harta kita

Allah tak melihat jabatan kita

Allah hanya lihat ibadah kita

sholat yang utama

dari semua fenomena yang terjadi terlihat ada emosi dalam diri tuk benahi kedamaian dan damaikan hati

yang menjadi ambisi-ambisi tak terkendali

kita satukan visi dan misi kita demi untuk cinta yang damaikan dunia

kita bersama bisa merasakan kesejahteraan

tanpa perasaan iri satu sama lainnya 
M. T. Arifin, A. Muhlis, dan Nase

yakinlah apa yang Allah telah gariskan untuk kita

bahwa setiap perintah-perintah-Nya untuk kemaslahatan dunia

.... singkirkan sombong

kita saling berpegang tangan rapatkan barisan

Reff: Allah tak melihat harta kita

Allah tak melihat jabatan kita

Allah hanya lihat ibadah kita

Dalam menciptakan lirik lagu, para penciptanya tentu memiliki keinginan untuk menyampaikan sesuatu kepada para pendengarnya. Seperti lagu "Arti Cinta" karya Ari Laso, yang ingin menyampaikan tentang arti cinta, "Wanita Shaleha" karya bang Haji Roma Irama ingin menyampaikan mengenai perhiasan yang terindah di muka bumi adalah wanita shaleha. Begitu pun dengan Ebith Beat*A saat menulis lirik dalam lagu-lagu yang diciptakannya.

\section{PENUTUP}

Ebith Beat *A merupakan salah satu musisi ternama yang dikenal sebagai seorang rapper. Namun citra rapper yang selama ini kita ketahui sebagai pemusik yang mempunyai citra negative bisa dipatahkan oleh seorang Ebith Beat $A^{*}$. Pasalnya beliau menggunakan aliran musik hiphop yang biasa dilakukan oleh seorang rapper sebagai media dakwah. Pesan yang terdapat dalam albumnya merupakan interpretasi Ebith Beat A* sebagai sarana dakwah yang dikemas melalui musik yang tidak lazim digunakan oleh musisi muslim lainnya. Sehingga terdapat keunikan tersendiri dari apa yang dilakukan Ebith Beath $A^{*}$ dengan musik hiphopnya yang bisa digunakan sebagai alternative kegiatan dakwah dalam menjawab tantangan zaman yang semakin berkembang bersama tumbuh pesatnya era globalisasi. Ebith Beat A* telah membuktikan bahwasannya dakwah harus bersifat dinamis. Artinya, setiap kegiatan dakwah harus mempunyai jiwa yang bisa disampaikan kepada masyarakat dan mampu bersaing dengan lagu-lagu lain yang non islami sebagaimana mereka mampu membius masyrakat, terutama remaja muslim untuk menyukai euforia aliran musik yang mereka sajikan.

Pengemasan lirik lagu yang sama sekali tidak bertentangan dengan ajaran Islam, membuat beliau dikenal di semua kalangan. Akan tetapi, beliau berharap semoga dengan hadirnya beliau dengan lagu-lagu yang dibawakannya menjadi salah satu media dakwah bagi para remaja yang sebagian dari mereka tidak pernah mengikuti pengajian mimbar ke 
mimbar, masjid ke masjid, panggung ke panggung, dan sebagainya. Pesan dakwah yang terkandung dalam album "Ketika Hati Bicara" terbilang lengkap. Pesan akhlak, akidah, dan syariahnya terkandung di sana. Dalam lagu ini terdapat dua kategori pesan dakwah, yaitu akidah: bagaimana kita percaya bahwa semua yang terjadi di dunia ini sudah ada yang mengaturnya. Kita cukup usahakan dan pasrahkan segalanya. Akhlak: sudah sepantasnya antarmanusia saling mengingatkan ketika salah satu diantaranya melakukan kekhilafan. Bukan hanya itu, di dalamnya juga terdapat gambaran bahwa sikap meminta ampun kepada Tuhan salah satunya dengan cara bersujud.

Saran penyusun untuk peneliti selanjutnya adalah ketika lagu-lagu yang dinyanyikan oleh Ebith Beat A* bisa dijadikan sebagai salah satu media dakwah oleh para juru da'i, terutama bagi mereka yang menyampaikan ceramahnya dengan menyisipkan sentuhan lagu, maka untuk penelitian selanjutnya, peneliti berharap ada penelitian tentang respon para pendengar musik Ebith Beat $\mathrm{A}^{*}$ dalam meningkatkan kadar keimanan kepada Allah Swt dan penelitian selanjutnya bisa lebih membuka setiap makna melalui analisis semiotika milik Rollan Bartes. Disamping itu, lagu-lagu Ebith Beat $A^{*}$ sangat recommended bagi para kawula muda yang senang dengan musik, terutama hip-hop. Pasalnya, lagu-lagu Ebith Beath $A^{*}$ bisa menjadi salah satu alternatif pengingat kepada sang pencipta Allah Swt. Jika diibaratkan, Ebith Beat A* bernyanyi seperti halnya ia sedang ceramah dan menyampaikan pesan-pesan Quran dan Hadits kepada para mad'unya.

\section{DAFTAR PUSTAKA}

Aripudin, A. (2013). Sosiologi Dakwah. Bandung: PT Remaja Rosdakarya. Bachtiar. (1997) Metodologi Penelitian Ilmu Dakwah. Jakarta: Logos.

Departement Pendidikan dan Kebudayaan RI. (1999) Kamus Besar Bahasa Indonesia .Jakarta: Perum Balai Pustaka.

Hasanuddin. (1996) Hukum Dakwah. Jakarta: Pedoman Ilmu Jaya. Hamju, A. (1998) Pengetabuan Seni Musik .Bandung: PT Remaja Rosdakarya

Hikmat. (2011). Pesan-Pesan Dakwah dalam Bahasa Tutur. Imu Dakwah: Academic Journal for Homiletic 4(14), 689-698.

Mulyana, D. (2005). Ilmu Komunikasi: Suatu Pengantar. Bandung: PT. Remaja Rosdakarya.

Arifin M. (2006). Psikologi Dakwah Suatu Pengantar Studi. Jakarta: Bumi 
M. T. Arifin, A. Muhlis, dan Nase

Aksarah.

Syukir, A. (1983) Strategi Dakwah. Surabaya: Al-Ikhlas.

Efendy (1999). Ilmu Komunikasi: Teori dan Praktek. Bandung: PT. Remaja Rosdakaraya.

Umar, Y. (1983) Hukum Seni Musik, Tari, Suara dalam Islam. Jakarta: Wijaya. 